\title{
Control of woody plants in grazing lands on the Pacific Coast of Mexico
}

\author{
M. GARCIA-HOLQUIN, R.W. BOVEY, AND J.L. SCHUSTER
}

\begin{abstract}
Greenhouse and field experiments were conducted to evaluate herbicides for control of Palma de llano (Sabal rosei Mart.), jarretadera (Acacia hindsii Benth), huinol (Acacia cymbispina Sprague \& Riley), and guazima (Guazuma ulmifolia Lam.), woody species encroaching in grazing lands on the Pacific Coast of Mexico. In the greenhouse, picloram at 0.14 and $0.28 \mathrm{~kg}$ ae $/ \mathrm{ha}$ killed all jarretadera, huinol, and guazima plants. Mixtures of picloram + clopyralid, dicamba, or triclopyr at $0.07+0.07$ and $0.14+0.14$ $\mathrm{kg} / \mathrm{ha}$ also killed most plants. Triclopyr killed all huinol at 0.14 and $0.28 \mathrm{~kg} / \mathrm{ha}$ but not all jarretadera or guazima. Clopyralid was effective on jarretadera and huinol but not as effective as picloram. Dicamba was ineffective on jarretadera and killed 88 to $100 \%$ of the huinol and guazima plants at $0.28 \mathrm{~kg} / \mathrm{ha}$. The palm could not be grown in the greenhouse. In the field, foliar sprays of triclopyr or picloram at 0.4 and $0.3 \mathrm{~g}$ ae/ $\mathrm{L}$ water, respectively, killed $70 \%$ or more of the jarretadera, huinol and guazima but $77 \%$ or less of the palm. No herbicide successfully controlled jarretadera in 1988. Hexazinone applied to the soil killed $82 \%$ or more of the palm plants at $0.5 \mathrm{~g}$ ai $/ 2.5 \mathrm{~cm}$ of stem diameter. Soil-applied tebuthiuron pellets were not effective on jarretadera or palm, but the briquettes (Brush Bullets) at 2 and $4 \mathrm{~g} / 2.5 \mathrm{~cm}$ of stem diameter killed 50, 60, and $83 \%$ or more of the huinol, palm, and guazima plants, respectively.
\end{abstract}

Key Words: Sabal rosei, A cacia hindsii, Acacia cymbispina, Guazuma ulmifolia, Clopyralid, dicamba, hexazinone, picloram, tebuthiuron, triclopyr

\footnotetext{
Authors are research assistant, Department of Rangeland Ecology and Management, Texas A\&M University, College Station 77843; research agronomist, USDAARS, Southern Crops Research Laboratory, Pest Management Research Unit. College Station; and professor and head, Department of Rangeland Ecology and Management, Texas A\&M University, College Station 77843.

Mention of trademark name of proprietary product does not constitute a guarantee or warranty of the product by the USDA or Texas A\&M University and does not imply its approval to the exclusion of other products that may also be suitable.

Manuscript accepted 24 February 1991.
}

Most grazing lands of Mexico, particularly the subtropical Pacific coast, support undesirable woody plants. Overgrazing, suppression of natural fires, fluctuations in climate, and mechanical soil disturbance for pasture establishment may have hastened woody plant encroachment. Major weed problems include Palma de llano (Sabal rosei mart.) jarretadera (Acacia hindsii Benth.), huinol (Acacia cymbispina Sprague and Riley.) and guazima (Guazuma ulmifolia Lam.), and on deteriorated rangeland and pastures these species have become dominant.

Jarretadera and huinol are woody plants belonging to the Leguminoseae family (Wiggins 1980, Martinez 1939). Huinol is a thorny plant which grows upright from a single-stem whereas jarretadera varies in growth form from a single-stemmed to a multi-stemmed tree. The growth form of jarretadera is often the result of sprouting following injury or top removal by fire. Increase in density and spread of huinol occurs only from seeds, but jarretadera spreads from seeds and roots.

Palma de llano belongs to the Palmae family and forms a unique single-stemmed tree with a large straight trunk. It commonly occurs on rangelands subjected to fire. Guazima is a shrub or tree up to $20 \mathrm{~m}$ tall with a trunk often 30 to $40 \mathrm{~cm}$ in diameter (Standley 1920-1926). It belongs to the Cacao family (Stercutiaceae) and frequently grows in thickets along arroyos. Guazima seed are easily spread in cattle manure since fruit and leaves are often eaten by cattle when forage availability is low. Guazima is widely distributed in tropical America.

High densities of these woody plants not only reduce forage production but impede livestock grazing and movement. All produce a large amount of viable seed conducive to widespead dissemination on rangelands.

No specific control recommendations are available for these undesirable shrubs but herbicides have been developed for control

JOURNAL OF RANGE MANAGEMENT 44(5), September 1991 
of similar problems in other countries, particularly the United States. Tebuthiuron $\{N$-[5-(1,1-dimethylethyl)-1,3,4-thiadiazol-2yl]- $N, N$-dimethylurea\} applied to the soil as pellets controls many weeds and woody plants (Bovey 1987, Anonymous 1989, Welch 1988), especially oak species at rates of 0.6 to $4.2 \mathrm{~kg} /$ ha. Hexazinone [3-cyclohexyl-6-(dimethylamino)-1-methyl-1,3,5,-triazine-2, $4(1 \mathrm{H}, 3 \mathrm{H})$-dione] is also effective through root uptake but hexazinone is usually applied as the undiluted miscible liquid. (Bovey 1987, Welch 1988). Hexazinone has wide usage for annual and perennial weeds, woody plants, and for selective weed control in certain crops. Growth regulators, systemic herbicides including clopyralid (3,6-dichloro-2-pryidinecarboxylic acid), dicamba (3,6dichloro-2-methoxybenzoic acid), picloram (4-amino-3,5,6-trichloro-2-pyridinecarboxylic acid), and triclopyr $\{[(3,5,6-t$ richloro2-pyridinyl)oxy]acetic acid\}, also are highly effective in controlling certain woody plants from foliar spray applications. They are also effective from root uptake (Bovey 1987). Picloram is active on a wide spectrum of woody plants, while clopyralid, dicamba, and triclopyr are more selective.

The objectives of this study were to evaluate the response of greenhouse-grown jarretadera, huinol, and guazima to clopyralid, dicamba, hexazinone, picloram, tebuthiuron, and triclopyr and all paired 1:1 mixtures of clopyralid, dicamba, picloram, and triclopyr. The purpose was to develop control measures for these species, including palm de llano in the field, using the most promising herbicides based on greenhouse and related field research.

\section{Materials and Methods}

\section{Greenhouse Treatments}

Plants of jarretadera, huinol, and guazima were grown from seeds in the greenhouse in pots $(10 \mathrm{~cm}$ in diameter by $10 \mathrm{~cm}$ deep) containing a 1:1:1 (v/v/v) mixture of Bleiblerville clay (fine, montmorillonitic Udic Pellusterts), sand, and peatmoss during summer months when daytime temperature was approximately $35^{\circ} \mathrm{C}$ and night temperature was $25^{\circ} \mathrm{C}$. To improve germination, seed of jarretadera and huinol were emersed in concentrated $\mathrm{H}_{2} \mathrm{SO}_{4}$ for 30 and minutes, respectively, before rinsing with water and planting. Seeds of guazima were emersed in water for 20 minutes to remove a waxy coating before immersing in concentrated $\mathrm{H}_{2} \mathrm{SO}_{4}$ for 15 minutes. The plants were grown for 2 to 3 months after seeding, and huinol, jarretadera, and guazima were 45,15 , and $15 \mathrm{~cm}$ tall, respectively, and had 17,9 , and 7 leaves per plant when treated in 1988, respectively. In 1989, huinol, jarretadera, and guazima were 25,15 , and $10 \mathrm{~cm}$ tall and averaged 16,10 , and 8 leaves per plant, respectively, when treated.

Herbicide treatments were foliar sprays of commercial formulations of the monoethanolamine salt of clopyralid, dimethylamine salt of dicamba, miscible liquid concentrate of hexazinone, potassium salt of picloram, $80 \%$ wettable powder of tebuthiuron, and the butoxyethyl ester of triclopyr. Hexazinone and tebuthiuron were applied at 0.28 and $0.56 \mathrm{~kg}$ ai/ha. Clopyralid, dicamba, picloram, and triclopyr were applied alone at 0.14 and $0.28 \mathrm{~kg}$ ae/ ha and in all possible $1: 1$ mixtures at $0.07+0.07$ and $0.14+0.14$ $\mathrm{kg}$ ae/ha. All herbicides were applied in a water carrier at the equivalent volume of $94 \mathrm{~L} /$ ha with a pressure of $210 \mathrm{kPa}$ in a laboratory spray chamber (Bouse and Bovey 1967). All plants were returned to the greenhouse immediately after treatment. The potted plants were watered 24 hours after herbicide treatment and daily thereafter.

Percentage of dead stem tissue of each plant was visually estimated 2 months after treatment. Plants with $100 \%$ dead leaves and stems with no resprouts were considered dead. Experiments for all species were conducted twice with applications on 16 June 1988 and 28 June 1989. A completely randomized design was used with 8 replications (plants) for each herbicide treatment. Data were sub- ected to analysis of variance following an arcsine $\sqrt{x}$ transformation (where $\boldsymbol{x}$ is proportion), and means were separated by the Tukey's Studentized Range Test at the 5\% level (Steel and Torrie 1980). A date-by-treatment interaction was significant so data for the 2 dates of application are presented separately.

\section{Field Treatments}

The field phase of the study was conducted in the "Gilberto Flores Munoz" Experiment Station of the National Institute for Forestry, Agriculture, and Livestock Research (INIFAP), a division of the Ministry of Agriculture (SARH) of Mexico, in the county of Santiago Ixcuintla in the State of Nayarit. According to the Keoppens climate classification modified for Mexico by Garcia (1973), the climate of the area is subhumid, with a mean annual precipitation of $1,000 \mathrm{~mm}$ distributed mainly from June to October. The annual mean temperature is $24^{\circ} \mathrm{C}$.

The elevation of the study area ranges from 30 to $50 \mathrm{~m}$ above sea level, and the vegetation type corresponds to a semievergreen seasonal forest with huanacaxtle [ Enterolobium clyocarpum (Jack.) Griseb.], ceiba [Ceiba pentandra(L)Gaerth], capomo (Brosimum alicastrum Swartz.), rosamarilla [Cochlospermum vitifolium (Willd.) Spreng.], haba (Hura pilyandra Baill.), amapa [Tabebuia rosea (Bertol.) DC., guamuchii [ Pithecellobium dulce (Roxb.) Benth], caoba (Swietenia humillis Zucc.), papelillo [Bursera arborea(L)Sarg.], and higuera (Ficus padifolia HBK., F. Glabrata Miq., and $F$. continifoia HBK.) as dominant species in the highest stratum and zacate de llano (Paspalum multicaule, P. plicatulum Michx.), zacate gusano [Setaria geniculata (Lam.) Beauv.] navajita velluda (Bouteloua hirsuta Lag.), carricillo or popotillo (Andropogon hirtiflorus Nees.), moreno (Heteropogon contortus), zacate cabeza de burro (Paspalum notatum Flugge.), zacate tempranero annual ( Hilaria ciliata HBK.), camalote (Paspalum multicaule), canuela (Cathestecum erectum Vasey \& Hock.), navajita morada (Boutleoua radicosa Lag.), and others in the herbaceous stratum. Topography is representative of flat-low areas and smooth hills. Soils are of in situ origin, and they are classified as chernozems of lathyritic group of red, reddish brown, and/or yellow color. Soil texture varies from clay to loamy-clay, and the $\mathrm{pH}$ ranges between 6 to 6.7 .

The experimental field units consisted of a total of 450 plants chosen at random for each species (palm, jarretadera, huinol, and guazima) each of 2 years. Plant height ranged from 0.8 to $1.8 \mathrm{~m}$. During the active growth cycle of the shrubs, each herbicide treatment was applied to 30 plants of each species (15/year) with each plant being considered a replicate. The experiments were applied in August 1987 and repeated in August 1988. All species had fully expanded leaves at time of treatment and had produced mature fruit. Temperature during application ranged from 25 to $30^{\circ} \mathrm{C}$, with a relative humidity of $>90 \%$. Herbicides were applied during the peak of the rainy season, with intermittent rainfall occurring during the week of treatment in late August (Table 5). Spray volumes of $0.4,0.8$, and $2.3 \mathrm{~g}$ ae/ $\mathrm{L}$ of water for the butoxyethyl ester of triclopyr and $0.3,0.6$, and $1.8 \mathrm{~g}$ ae/ $\mathrm{L}$ of water for the potassium salt of picloram were used. Herbicides were applied directly to the plants until thoroughly wet using a hand-carried sprayer. Hexazinone was applied directly to the soil, under the canopy of each plant within a distance of $1 \mathrm{~m}$ from the base of the stem. Hexazinone was applied undiluted using a hand applicator (syringe) at rates of 2,4 , and $8 \mathrm{ml}(0.5,1,2 \mathrm{~g}$ ai) $/ 2.5 \mathrm{~cm}$ of stem diameter at the base of the plant. Tebuthiuron pellets were applied broadcast at rates of 1,2 , and $4 \mathrm{~kg}$ ai/ha. Four, 8 or 16 briquettes $(0.25 \mathrm{~g}$ ai/briquette), Brush Bullets, were applied broadcast under the canopy of each plant to approximate 1,2 , and $4 \mathrm{~g}$ ai tebuthiuron $/ 2.5 \mathrm{~cm}$ of stem diameter.

Plants were evaluated 15 months after herbicide application by visually estimating percentage of dead stem tissue. Plants having 
$100 \%$ dead leaves and stems with no resprouts were considered dead. Data were analyzed as a completely randomized design with means compared by using Tukey's Studentized Range Test at the $5 \%$ level as described for the greenhouse experiments. A date-bytreatment interaction was significant so data for the $\mathbf{2}$ dates of application were presented separately.

\section{Results and Discussion}

\section{Greenhouse Treatments}

Picloram is a highly effective herbicide on many weed and brush species (Bovey 1977). The species investigated in this report were also highly susceptible to picloram or 1:1 mixtures of picloram + clopyralid, dicamba, or triclopyr. Picloram consistently killed all woody species at 0.14 and $0.28 \mathrm{~kg} / \mathrm{ha}$ in the greenhouse (Tables 1

Table 1. Percent mortality of jarretadera (Acacia hindsii), huinol (A. cymbispina), and guaxima (Guazuma ulmifolia) plants after application of 24 herbicide treatments in the greenhouse in 1988.

\begin{tabular}{|c|c|c|c|c|}
\hline \multirow[b]{2}{*}{ Herbicide } & \multirow[b]{2}{*}{ Rate } & \multicolumn{3}{|c|}{ Species } \\
\hline & & Jarretadera & Huinol & Guazima \\
\hline & $(\mathrm{kg} / \mathrm{ha})$ & -------- & $-(\%)-$ & $\ldots$ \\
\hline Triclopyr & 0.14 & 0 & 100 & 0 \\
\hline Triclopyr & 0.28 & 38 & 100 & 75 \\
\hline Picloram & 0.14 & 100 & 100 & 100 \\
\hline Picloram & 0.28 & 100 & 100 & 100 \\
\hline Clopyralid & 0.14 & 63 & 50 & 0 \\
\hline Clopyralid & 0.28 & 100 & 100 & 25 \\
\hline Dicamba & 0.14 & 13 & 13 & 50 \\
\hline Dicamba & 0.28 & 13 & 50 & 88 \\
\hline Triclopyr + Picloram & $.07+.07$ & 100 & 100 & 88 \\
\hline Triclopyr + Picloram & $.14+.14$ & 100 & 100 & 100 \\
\hline Triclopyr + Clopyralid & $.07+.07$ & 88 & 100 & 13 \\
\hline Triclopyr + Clopyralid & $.14+.14$ & 100 & 100 & 63 \\
\hline Triclopyr + Dicamba & $.07+.07$ & 13 & 100 & 50 \\
\hline Triclopyr + Dicamba & $.14+.14$ & 63 & 100 & 100 \\
\hline Picloram + Clopyralid & $.07+.07$ & 100 & 100 & 88 \\
\hline Picloram + Clopyralid & $.14+.14$ & 100 & 100 & 100 \\
\hline Picloram + Dicamba & $.07+.07$ & 88 & 100 & 100 \\
\hline Picloram + Dicamba & $.14+.14$ & 100 & 100 & 100 \\
\hline Clopyralid + Dicamba & $.07+.07$ & 75 & 75 & 38 \\
\hline Clopyralid + Dicamba & $.14+.14$ & 100 & 100 & 100 \\
\hline Hexazinone & 0.28 & 13 & 75 & 13 \\
\hline Hexazinone & 0.56 & 75 & 100 & 88 \\
\hline Tebuthiuron & 0.28 & 0 & 0 & 0 \\
\hline Tebuthiuron & 0.56 & 0 & 0 & 38 \\
\hline Control & 0 & 0 & 0 & 0 \\
\hline Tukey's 't' test $(.05)$ & & 52 & 39 & 59 \\
\hline
\end{tabular}

and 2). At similar rates, picloram + clopyralid killed all species except guazima at $0.07+0.07 \mathrm{~kg} / \mathrm{ha}$ where $88 \%$ of the plants were killed. Similarly picloram + triclopyr or dicamba at $0.07+0.07$ or $0.14+0.14 \mathrm{~kg} / \mathrm{ha}$ killed most plants.

Triclopyr was highly effective on huinol, killing all plants at 0.14 and $0.28 \mathrm{~kg} / \mathrm{ha}$ but was less effective on jarretadera and guazima, especially at $0.14 \mathrm{~kg} / \mathrm{ha}$ in 1988 when no plants were killed (Tables 1 and 2). Triclopyr at $0.28 \mathrm{~kg} / \mathrm{ha}$ killed more jarretadera and guazima than at $0.14 \mathrm{~kg} / \mathrm{ha}$. Triclopyr + picloram effectively controlled all woody species, whereas, triclopyr + clopyralid were most effective on jarretadera and huinol. Triclopyr + dicamba at $0.07+$ $0.07 \mathrm{~kg} /$ ha killed only $13 \%$ of the jarretadera plants.

Clopyralid was effective on the Acacia species especially at 0.28 $\mathrm{kg} / \mathrm{ha}$ but not very effective against guazima in 1988 (Tables 1 and 2). Clopyralid is highly effective against members of the Polygonaceae, Compositae, and Leguminosae families but shows little activity against grasses or crucifers (Anonymous 1989). Clopyralid activity was not reduced on the woody species in this report by
Table 2. Percent mortality of jarretudera (Acacia hindsii), huinol (A. cymbispina), and guazima (Guaruma ulmifolla) plants after application of 24 herbicide treatments in the greenhouse in 1989.

\begin{tabular}{|c|c|c|c|c|}
\hline \multirow[b]{2}{*}{ Herbicide } & \multirow[b]{2}{*}{ Rate } & \multicolumn{3}{|c|}{ Species } \\
\hline & & Jarretadera & Huinol & Guazima \\
\hline & (kg/ha) & \multicolumn{3}{|c|}{$-\ldots \ldots(\%)-\ldots \ldots$} \\
\hline Triclopyr & 0.14 & 0 & 100 & 63 \\
\hline Triclopyr & 0.28 & 75 & 100 & 100 \\
\hline Picloram & 0.14 & 100 & 100 & 100 \\
\hline Picloram & 0.28 & 100 & 100 & 100 \\
\hline Clopyralid & 0.14 & 88 & 76 & 13 \\
\hline Clopyralid & 0.28 & 100 & 100 & 88 \\
\hline Dicamba & 0.14 & 13 & 63 & 88 \\
\hline Dicamba & 0.28 & 38 & 100 & 100 \\
\hline Triclopyr + Picloram & $.07+.07$ & 100 & 100 & 100 \\
\hline Triclopyr + Picloram & $.14+.14$ & 100 & 100 & 100 \\
\hline Triclopyr + Clopyralid & $.07+.07$ & 100 & 100 & 25 \\
\hline Triclopyr + Clopyralid & $.14+.14$ & 100 & 100 & 75 \\
\hline Triclopyr + Dicamba & $.07+.07$ & 13 & 100 & 63 \\
\hline Triclopyr + Dicamba & $.14+.14$ & 25 & 100 & 100 \\
\hline Picloram + Clopyralid & $.07+.07$ & 100 & 100 & 100 \\
\hline Picloram + Clopyralid & $.14+.14$ & 100 & 100 & 100 \\
\hline Picloram + Dicamba & $.07+.07$ & 100 & 100 & 88 \\
\hline Picloram + Dicamba & $.14+.14$ & 100 & 100 & 100 \\
\hline Clopyralid + Dicamba & $.07+.07$ & 63 & 88 & 50 \\
\hline Clopyralid + Dicamba & $.14+.14$ & 100 & 100 & 88 \\
\hline Hexazinone & 0.28 & 13 & 88 & 38 \\
\hline Hexazinone & 0.56 & 88 & 100 & 75 \\
\hline Tebuthiuron & 0.28 & 0 & 0 & 25 \\
\hline Tebuthiuron & 0.56 & 0 & 100 & 50 \\
\hline Control & 0 & 0 & 0 & 0 \\
\hline Tukey's 't' test (.05) & & 47 & 32 & 63 \\
\hline
\end{tabular}

addition of dicamba, triclopyr, or dicamba at equivalent rates.

Dicamba at 0.14 and $0.28 \mathrm{~kg} / \mathrm{ha}$ was ineffective on jarretadera and huinol in 1988 and moderately effective on guazima. Dicamba at $0.28 \mathrm{~kg} / \mathrm{ha}$ in $1989 \mathrm{killed}$ all huinol and guazima plants and more than $63 \%$ of the plants at $0.14 \mathrm{~kg} / \mathrm{ha}$ but was ineffective on jarretadera. Mixtures of dicamba with triclopyr, picloram, or clopyralid generally enhanced the activity of the mixture on these species especially with picloram or clopyralid. Dicamba is moderately effective against huisache in Texas and may be useful for control of huinol and guazima in Mexico (Bovey 1977).

Hexazinone was effective on huinol at 0.28 and $0.56 \mathrm{~kg} / \mathrm{ha}$ and on jarretadera and guazima at $0.56 \mathrm{~kg} / \mathrm{ha}$ (Tables 1 and 2). Tebuthiuron, however, was usually ineffective applied as a wettable powder at 0.28 or $0.56 \mathrm{~kg} / \mathrm{ha}$ on these species. Data were also analyzed for percent dead stem tissue for each species discussed, and the data are almost identical to the mortality data; therefore, only percent mortality data were presented in this report.

\section{Field Treatments}

Triclopyr applied as a wetting foliar spray at rates of $0.4,0.8,2.3$ $\mathrm{g} / \mathrm{l}$ was highly effective in killing jarretadera, huinol, and guazima plants in natural stands but was only moderately effective in killing palm (Tables 3 and 4). None of the herbicide treatments including triclopyr were effective against jarretadera after application in 1988 (Table 4). Reasons for poor jarretadera control are unknown but may be related to treatment of regrowth plants with extensive root systems from which resprouts occurred. Rainfall patterns were favorable since abundant precipitation occurred immediately before and after treatment in 1987 and 1988 (Table 5). Moderate to good control of palm was obtained with the $2.8 \mathrm{~g} / \mathrm{L}$ of triclopyr in the 1987 applications.

Picloram as a wetting foliar spray provided good control of all 
Table 3. Percent mortality of jarretadera (Acacia hindsit), huinol (A. cymbispina), palma de llano (Sabal rosei) and guazima (Guazuma ulmifolia) plants after application of 15 herbicide treatments in the Pacific Coast of Nayarit Mexico in 1987.

\begin{tabular}{|c|c|c|c|c|c|}
\hline \multirow[b]{2}{*}{ Herbicide } & \multirow[b]{2}{*}{ Rate } & \multicolumn{4}{|c|}{ Species } \\
\hline & & Jarretadera & Huinol & Palm & Guazima \\
\hline & & \multicolumn{4}{|c|}{$-1 \%-1,-1-1-1$} \\
\hline Triclopyr ${ }^{1}$ & 0.4 & 77 & 83 & 4 & 80 \\
\hline Triclopyr ${ }^{1}$ & 0.8 & 97 & 100 & 37 & 97 \\
\hline Triclopyr' & 2.3 & 83 & 100 & 70 & 97 \\
\hline Picloram 1 & 0.3 & 77 & 87 & 7 & 93 \\
\hline Picloram 1 & 0.6 & 80 & 97 & 50 & 97 \\
\hline Picloram 1 & 1.8 & 100 & 100 & 54 & 90 \\
\hline Hexazinone ${ }^{2}$ & 0.5 & 30 & 60 & 54 & 90 \\
\hline Hexazinone ${ }^{2}$ & 1.0 & 34 & 83 & 80 & 97 \\
\hline Hexazinone $^{2}$ & 2.0 & 50 & 93 & 97 & 100 \\
\hline Tebuthiuron $20 \mathrm{P}^{3}$ & 1 & 4 & 70 & 0 & 64 \\
\hline Tebuthiuron $20 \mathrm{P}^{3}$ & 2 & 20 & 83 & 0 & 50 \\
\hline Tebuthiuron $20 \mathrm{P}^{3}$ & 4 & 24 & 97 & 0 & 77 \\
\hline $\begin{array}{l}\text { Tebuthiuron } \\
\text { (Brush Bullet) }\end{array}$ & $1(4)$ & 0 & 64 & 10 & 80 \\
\hline $\begin{array}{l}\text { Tebuthiuron } \\
\text { (Brush Bullet) }\end{array}$ & $2(8)$ & 7 & 60 & 50 & 83 \\
\hline $\begin{array}{l}\text { Tebuthiuron } \\
\text { (Brush Bullet) }\end{array}$ & $4(16)$ & 27 & 83 & 67 & 93 \\
\hline Tukey's ' $t$ ' test $(.05$ & & 33 & 30 & 33 & 29 \\
\hline
\end{tabular}

Table 4. Percent mortality of jarretadera (Acacia hindsii), huinol (A. cymbispina), palma de llano (Sabal rosei) and zuazima (Guazuma uimifolia) plants after application of 15 herbicide treatments in the Pacific Coast of Mexico in 1988.

\begin{tabular}{|c|c|c|c|c|c|}
\hline \multirow[b]{2}{*}{ Herbicide } & \multirow[b]{2}{*}{ Rate } & \multicolumn{4}{|c|}{ Species } \\
\hline & & Jarretadera & Huinol & Palm & Guazima \\
\hline & & \multicolumn{4}{|c|}{$-\ldots(\%)-\ldots-1-1$} \\
\hline Triclopyr' & 0.4 & 24 & 100 & 30 & 93 \\
\hline Triclopyr $^{1}$ & 0.8 & 27 & 90 & 34 & 93 \\
\hline Triclopyr' 1 & 2.3 & 24 & 97 & 7 & 100 \\
\hline Picloram & 0.3 & 24 & 83 & 77 & 70 \\
\hline Picloram ${ }^{1}$ & 0.6 & 44 & 93 & 60 & 93 \\
\hline Picloram ${ }^{1}$ & 1.8 & 30 & 93 & 67 & 47 \\
\hline Hexazinone $^{2}$ & 0.5 & 0 & 54 & 90 & 78 \\
\hline Hexazinone ${ }^{2}$ & 1.0 & 40 & 80 & 97 & 90 \\
\hline Hexazinone $^{2}$ & 2.0 & 34 & 93 & 100 & 100 \\
\hline Tebuthiuron 20P3 & 1 & 0 & 4 & 64 & 0 \\
\hline Tebuthiuron $20 \mathrm{P}^{3}$ & 2 & 10 & 24 & 0 & 60 \\
\hline Tebuthiuron $20 \mathrm{P}^{3}$ & 4 & 0 & 4 & 10 & 40 \\
\hline $\begin{array}{l}\text { Tebuthiuron } \\
\text { (Brush Bullet) }^{4}\end{array}$ & $1(4)$ & 4 & 47 & 40 & 87 \\
\hline $\begin{array}{l}\text { Tebuthiuron } \\
\text { (Brush Bullet) }\end{array}$ & $2(8)$ & 10 & 100 & 64 & 93 \\
\hline $\begin{array}{l}\text { Tebuthiuron } \\
\text { (Brush Bullet) }^{4}\end{array}$ & $4(16)$ & 7 & 77 & 90 & 100 \\
\hline Tukey's 't' test (.05 & & 32 & 28 & 34 & 29 \\
\hline
\end{tabular}

${ }^{1} \mathrm{~g}$ ae/ $\mathrm{L}$ of water

$2 \mathrm{~g} \mathrm{ai} / 2.5 \mathrm{~cm}$ of stem diameter

${ }^{3} \mathrm{~kg}$ ai/ha (20\% ai, 3.2-mm-diameter extruded pellets)

$4 \mathrm{~g}$ ai $/ 2.5 \mathrm{~cm}$ of stem diameter and number of bullets (Graslan Brush Bullet 250 are 1.8 $\mathrm{g}$ clay briquettes with $0.25 \mathrm{~g}$ ai tebuthiuron)

species but palm in 1987 (Table 3 and 4). In 1988, control of palm from picloram was improved over 1987 treatments but control of jarretadera was reduced. Hexazinone gave poor control of jarre-
Table 5. Monthly precipitation at the experimental site in the "Gilberto Flores Munoz" Experiment Station, National Institute of Forestry, Agriculture and Livestock Research, Nayarit Mexico.

\begin{tabular}{lcc}
\hline & \multicolumn{2}{c}{ Santiago, Mexico } \\
\cline { 2 - 3 } Month & 1987 & 1988 \\
\hline & & \\
January & 0.2 & 0.1 \\
February & 0.0 & 0.0 \\
March & 0.0 & 6.0 \\
April & 0.8 & 1.7 \\
May & 42.5 & 0.0 \\
June & 219.3 & 152.9 \\
July & 348.6 & 317.2 \\
August & 325.3 & 356.2 \\
September & 63.3 & 450.2 \\
October & 0.6 & 15.7 \\
November & 1.2 & 0.0 \\
December & 101.8 & 3.0 \\
Total & & 1303.0 \\
\hline
\end{tabular}

tadera in 1987 and 1988 but killed 80 to $100 \%$ of the huinol, palm, and guazima plants at rates of 1 or $2 \mathrm{~g} / 2.5-\mathrm{cm}$ stem diameter. Hexazinone was highly effective for palm control, especially at 1 or $2 \mathrm{~g} / 2.5 \mathrm{~cm}$ stem diameter killing $80 \%$ or more of the plants.

Tebuthiuron pellets controlled huinol in 1987 and was moderately effective in killing guazima in 1987 and 1988 (Tables 3 and 4). Control of jarretadera and palm was poor at all rates of tebuthiuron pellets. Tebuthiuron applied as "Brush Bullets" were highly effective on guazima, killing 80 to $100 \%$ of the plants in the 1987 and 1988 treatments. Brush Bullets were also effective on huinol and palm plants, killing $50 \%$ or more of the plants at rates of 2 or 4 $\mathrm{g} / 2.5 \mathrm{~cm}$ of stem diameter. Rates of $4 \mathrm{~g} / 2.5 \mathrm{~cm}$ of stem diameter killed 67 and $90 \%$ of the palm trees in the 1987 and 1988 treatments, respectively.

The benefit of removing aerial growth and reducing woody plant competition may not be fully realized by mortality data alone. Triclopyr, for example, killed a high percentage of stem tissue of all species reported but showed poor kill of palm in 1987 and 1988 and poor kill of jarretadera in 1988 (Data not shown). Picloram also killed a high percentage of stem tissue on all species. Hexazinone killed $85 \%$ or more of the stem tissue of all species in the 1987 and 1988 treatments at 1 and $2 \mathrm{~kg} /$ ha with the exception of jarretadera, which was resistant. Results for tebuthiuron were variable with good (75\%) to excellent ( $90 \%$ or more) killing of stems for most treatments. Stem kill of jarretadera treated in 1988 was poor.

Triclopyr and picloram control many broadleaf weeds and woody plants (Anonymous 1989, Welch 1988) and showed promise for control of the species reported here. Palm was most resistant to triclopyr and picloram but was susceptible to hexazinone. Tebuthiuron is also an excellent brush control herbicide (Bovey 1987) but resulted in poor control of jarretadera and palm in 1987 and all species in 1988 applied as pellets. Briquettes or "Brush Bullets" of tebuthiuron were more effective on palm than pellets and killed a high percentage of huinol and guazima plants but was weak on jarretadera. Data indicated effective control of these species are possible with commercially available herbicides and that application of one or more herbicides alone or in mixtures on specific species may be useful for pasture improvement for control of jarretadera, huinol, palms, or guazima on the Pacific coast of Mexico.

\section{Literature Cited}

Anonymous. 1989. Herbicide handbook of the Weed Science Society of America 6th ed. Herbicide Handbook Comm. WSSA. 
Bouse, L.F., and R.W. Bovey. 1967. A laboratory sprayer for potted plants. Weeds 15:89-91.

Bovey, R.W. 1977. Response of selected woody plants in the United States to herbicides USDA-ARS Agr. Handb. 493.

Bovey, R.W. 1987. Weed control problems, approaches and opportunities in rangeland. Review of Weed Science 3:57-91.

Garcia, E. 1973. Modificacione al sistema de classigicacion climatica de Koeppen. Instituto de Geografia, UNAM. Za Ed. Mexico, D.F.

Martinez, M. 1939. Tas Plantas Medicinales de Mexico. 2nd Ed. Ediciones Botas Mexico.
Standley, Paul C. 1920-1926. Contributions from the U.S. National Herbarium. Vol. 23, Trees and Shrubs of Mexico. U.S. Printing Off. Washington, D.C.

Steel, R.G.D., and J.H. Torrie. 1980. Principles and procedures of statistics, a biometrical approach. McGraw-Hill Book Co., New York.

Welch, T.G. 1988. Suggestions for chemical weed and brush control on rangeland. Texas Agr. Ext. Serv., Texas A\&M Univ. B-1466.

Wiggins, J.T. 1980. Flora of Baja California. Standford Univ. Press, Standford, Calif. 